\title{
Teaching Methods for Generation $Z$ for Physical Activities: a Stable Labor Market Provision under the COVID-19 Pandemic
}

\author{
IVARS KRAVALIS \\ Department of Skiing, Shooting, Orienteering, Rowing, Tourism and Recreation \\ Latvian Academy of Sport Education \\ Brivibas Street 333, Riga, LV1006 \\ LATVIA \\ KALVIS CIEKURS* \\ Department of Skiing, Shooting, Orienteering, Rowing, Tourism and Recreation \\ Latvian Academy of Sport Education \\ Brivibas Street 333, Riga, LV1006 \\ LATVIA \\ ANASTASIJA ROPA \\ Department of Sport Management and Communication Science \\ Latvian Academy of Sport Education \\ Brivibas Street 333, Riga, LV1006 \\ LATVIA \\ INESE MAVLUTOVA \\ Department of Economics and Finance \\ BA School of Business and Finance \\ Kr. Valdemara 161, LV-1013, Riga \\ LATVIA \\ JANIS HERMANIS \\ Department of Economics and Finance \\ BA School of Business and Finance \\ Kr. Valdemara 161, LV-1013, Riga \\ LATVIA
}

\begin{abstract}
Over a year has passed since the beginning of Covid-19 pandemic and the introduction of measures to limit the spread of the pandemic in Latvia. These have resulted in changes in all spheres of young people's lives, including the way they study and exercise. This study examines the role of Generation $\mathrm{Z}$ physical activity as a means of maintaining the wellbeing of the emerging workforce and the choice of teaching methods by different age groups and genders as well as the finances spent on it. The research methods include critical content analysis of scientific literature on Generation Z, modern teaching methods and the role of physical activity in young people's lives as well as descriptive statistical data analysis of primary data obtained from a questionnaire. The authors found positive correlation between age, gender, the occurrence of depressing mood or anxiety and engagement in physical activity and also identified that Generation $\mathrm{Z}$ spends less financial resources for their physical activities and well-being insurance (e.g., the empirical study shows that $84 \%$ of respondents spend under 20 hours per month on physical activity, with Chi-Square test $p=0.001$ ); additionally, the study shows that the use of such teaching methods as group work, seminars and webinars for promoting physical activities are efficient under the Covid-19 pandemic situation, except for
\end{abstract}


responders aged $16-19$, who do not enjoy seminars and conferences $(\mathrm{p}=0.002)$ and webinars $(\mathrm{p}=0.001)$, albeit other age groups do not mind these teaching methods as well as group work, as shown by Chi-Squared Test ( $>0.05)$.

Key-Words: Generation Z, physical activity, teaching methods, COVID-19 pandemic, labor market, well-being, Latvia

Received: April 15, 2021. Revised: October 27, 2021. Accepted: November 7, 2021. Published: November 25, 2021.

\section{Introduction}

The generation that is currently studying in secondary and higher education or has recently entered the employment market has been termed Generation Z; it is also sometimes referred to as the "net" generation or the "digital natives." One of the central events that informed the development of Generation $\mathrm{Z}$ is no doubt the emergence and spread of digital technologies, which is often viewed as the key characteristic of Generation Z. 38\% of Generation $\mathrm{Z}$ consider work-life balance as a key factor in choosing an employer, to create a good working environment for Generaton- $Z$ business managers need to promote a healthy lifestyle and a sustainable well-being [1].

The aim of this study is to investigate explores the role of physical activities and the choice of teaching methods by different groups within Generation $Z$ and the relation between the amount of sport activity, the finances spent on it and well-being of Generation $\mathrm{Z}$ representatives for stable future labor market.

As part of their recreation and in order to maintain health and well-being young people of Generation $Z$ are recommended to spend time outdoors, in natural environments, and engaging in sport activities particularly during Covid-19 pandemics, but also at other times. An important factor in adopting to the pandemic and finding sustainable ways of providing distance education is that Generation $\mathrm{Z}$ should understand the availability of IT provisions, including computers, tablets or mobile phones, as well as the Internet and powerful software for ensuring distance study. These considerations are particularly topical for Generation Z representatives in Latvia, because not everyone can afford to study over distance using this model.

In the context of restrictions imposed to limit the spread of Covid-19, providing instruction for sport education, facilitating physical exercise and motivating young people to be more physically active is particularly important to maintain their emotional and psychological health. Meanwhile, it is important to use appropriate teaching methods for instruction without or with limited contact with learners offline, in order to educate and motivate learners, while ensuring that quality standards are maintained in education.

\section{Literature review}

\subsection{Characteristics of Generation $\mathrm{Z}$ as emerging labor market workforce}

The term "digital natives," occasionally used to describe Generation Z, implies an opposition between Generation $\mathrm{Z}$ and the previous ones, who are then described as "digital immigrants" [2]. Although any precise chronological markers may be arbitrary, Generation $Z$ is generally described as comprising the individuals born between the late 1990s and $2010[3,4]$. Thus, some members of this generation would still be studying at secondary school, while others may be receiving secondary or even tertiary education or have already entered the employment market. As Dolot postulates, Generation $\mathrm{Z}$ is a generation that has 
already entered the labor market or is just entering it (having their first job or internship), or is studying and not working yet [5]. As a result, the issue of internal unity among the representatives of Generation $\mathrm{Z}$ arises, as it is described as an identifiable group of people who share a different set of features, values and significant historical events at the critical stage of development [6].

Rubene observes that the parents of Generation $\mathrm{Z}$ children strive to protect them from the dangerous world outside, which leads to excessive care and learned helplessness. Rubene also calls them "digital citizens" and "YouTube generation," who spend 24/7 online, and technologies are considered to be among the key aspects in the processes of their socialization and upbringing [7]. They had access through mobile phones, tablets and laptops from a very early age, in difference from the previous generations, who grew up without these gadgets [8].

This generation is motivated by tolerance, trust and new challenges, and their core values are freedom, selffulfillment, self-identity and happiness, insofar as they are sometimes perceived as self-centered and selfish. Improvements in technology, violence, the economic situation and social justice movements also could be mentioned as different features from previous generations $[7,8]$.

However, there is no scholarly agreement whether the fact that Generation $Z$ representatives were born into the world of technologies makes them radically different from the Millennials (Generation Y), or indeed, any other of the preceding generations. Today, people of all ages have access and are active on social media, with digital literacy being dependent not only on the generation, but also on one's cultural, economic, and even ethnic background [9, $10,11]$. It may be revealed that there are significant differences in the profile of Generation $\mathrm{Z}$ representatives in different parts of the world, among different European countries, or even within a single country, as at least one study devoted to European Generation Z shows [12, 13, 14].

At the same time, certain characteristics are repeatedly quoted as associated with Generation Z. Thus, they can function in both the real and the virtual worlds and easily switch between these two worlds, because they perceive them as complementary to one another [5]. Generation $\mathrm{Z}$ representatives are described as being good at sourcing and disseminating information quickly (though the quality of information may be more problematic), at communicating, especially through the use of social media [15], and at multitasking $[16,2,7]$. On the down side, they have shorter attention span $[17,18,2]$, are less able to discriminate between trustworthy and less trustworthy sources of information, often expect immediate satisfaction and are disengaged from society [8]. All of these characteristics have an impact on Generation $\mathrm{Z}$ learning strategies and styles, making certain methods more efficient than others in the sphere of education.

In describing Generation Z's attitudes to health, studies reveal that this group is more focused on the issues of emotional health, although they pay attention to physical health as well. At the same time, due to the fact that Generation $\mathrm{Z}$ spends so much time in virtual space, which constitutes an integral part of their lives, in times of crisis or when they seek to regain emotional balance, they tend to turn to virtual spaces, which is likely to have negative influence on their physical health and their emotional well-being [19]. This may be particularly true in the current situation caused by Covid-19 pandemics, when real-world opportunities for communication are largely limited or not available at all during the lockdown.

The lack of communication caused by the full or partial lockdown enacted in countries all around the world and the importance of socialization in order to facilitate a healthy lifestyle, maintain health and boost immunity has been the subject of 
numerous studies targeting various social and age groups, among them youngsters $[20,21,22,23]$. Whether or not virtual communication constitutes a viable alternative to in-person communication and instruction for Generation $\mathrm{Z}$ remains to be determined, yet earlier studies have highlighted the fact that Generation $\mathrm{Z}$ prefers in-person feedback and communication in education to the one provided via online channels. Thus, according to Csobanka and Dolat on-site activities are also important to them, however, keeping the online contacts have an equally important role $[24,5]$.

The importance of feedback has likewise been remarked in connection with Generation $\mathrm{Z}$ representatives as employees: this means delivering feedback to Generation $\mathrm{Z}$ in a way that is trackable. Stahl recommends an employer (or a lecturer) to address specific and tangible points that are as close to their behavior or results as possible in order to help them learn quickly and to explore using a technology portal that can track their performance [25]. Remarkably, Stahl suggests that Generation $Z$ has an idiosyncratic way of viewing failure: for them, failure is an opportunity to grow and learn. According to a recent report, $80 \%$ of Generation $\mathrm{Z}$ saw failure as something to embrace on their way to more innovation and learning; for them, mistakes provide motivation to persevere and to improve $[25,7]$.

Generation $\mathrm{Z}$ is not homogenous in terms of its social status and education: it is composed both of under-aged and adult people, with some young people studying at school or a higher education institution, others working and still others combining studies with work. However, as Dolot notes, there have been relatively few studies about Generation $\mathrm{Z}$ representatives on the labour market; still, the existing studies highlight the fact that Generation Zs are even more focused on life and family values than on building a career than the representatives of the previous Generation
$\mathrm{Y}$ [5]. In fact, $38 \%$ of Generation $\mathrm{Z}$ considers work-life balance as their primary factor in selecting an employer [1]. Regan further states that, in order to create a good working environment for Generation Z, employers must encourage a healthy way of life and robust well-being and lists ways to avoid burnout in the workplace, including unplugging from technology over the weekend and getting out into nature, starting a meditation group at one's workplace; and removing the work email from personal phone [1]. The authors agree with Regan and recommend employers to improve Generation Z's working conditions, by sending out surveys periodically to gauge how employees feel, setting up flexible time and offering remote work so that employees feel supported [1].

The issue of Generation $\mathrm{Z}$ employees getting out into nature as a way of recharging is particularly topical during Covid-19 pandemics and the associated restrictions, which make indoor recreation prohibited or limited in many cases. Spending time outdoors, or the so-called nature sports, have been recommended for all citizens, and the growth in these activities have been noted at the very outset of the pandemics $[26,27]$. According to the proponents of the Attention Restoration Theory (ART), nature provides a regenerative environment, which can be used through volunteer participation as well as through engaging in tasks which require attention: this way, where people can be recreated without getting tired. Çobanoğlu et al. states that outdoor areas provide mental and physical improvement and growth [28]. Thus, young people of Generation $\mathrm{Z}$ are recommended to spend time outdoors and in natural environments, particularly during Covid-19 pandemics, but also at other times.

Studies reveal that positive correlation has been outlined between the level of sport activity and mental health and reported well-being during Covid-19 pandemics in all age groups. Thus, Petersone et al. underline the aspect of 
achieving the goal of well-being and needs of changes in the provision of sustainable health care and its funding [29]. However, social isolation has been previously shown to be associated with both a decrease in sport activity levels and an increase in inactive behavior, which is particularly topical in view of the restrictions imposed during Covid-19 pandemics [21]. Thus, integrating sport activity and exercise into the learning of Generation $\mathrm{Z}$ representatives, both online and offline, is likely to enhance both physical and emotional health both during Covid-19 pandemics and outside it. While physical education may be harder to implement in online settings - or at least it has been less developed - it is important to maintain so that learners will stay active not only for the duration of their education but also afterwards. This aim is best achieved by programs that give learners a chance to exercise functional motor skills, develop fitness knowledge and perceived competence as well as view movement as joyful and not mundane [30].

\subsection{Methods for teaching sport activities to Generation $\mathbf{Z}$}

Modern pedagogy distinguishes between a variety of teaching methods that can be used in virtual and real classrooms. Already before the breakout of Covid-19 pandemics, the notion of the "school" or "traditional campus" has been subject to criticism due to its failure to take into account new technological developments and to cater for the needs of learners belonging to Generation Z. Suggesting that it may still be relevant as a setting in which the process of education would take place, they need to be provided to encourage students to actually attend campus and to meet face to face with their colleagues, rather than solely through social networking [31].

With the advent of Covid-19 pandemics, many educational opportunities were fully or partially moved online, further undermining the status of the traditional campus, but also highlighting the problems that e-learning faces. Not all teaching methods are equally well-adapted for the use in the online classroom due to the current access to technology (availability of computers, tablets, mobile phones, Internet access and powerful software for distance learning) [32]. An opinion was expressed that the process of distance studies at school influenced the final assessment at the exam and that the workload on students increased as compared to daily studies before the pandemic, when students attended the school in person. The situation was the subject of research in other studies, which looked at the ways in which distance studies influence the relations between the teacher and the students [33].

At the same time, by making necessary changes to the content, using appropriate IT solutions and adjusting the tasks, all of the teaching methods can be used in both virtual and real environments. Generation $\mathrm{Z}$ has in fact adopted quickly and is prepared to master the necessary material online; students often view this development as an advantage, because recorded lectures can be watched repeatedly at a convenient time. Meanwhile, teachers and lecturers believe that learning material this way facilitates the introduction of new material online if sufficient feedback and support is provided during the process of learning, as shown in a recent study conducted by Farneste and Apse during the pandemic that used both quantitative and qualitative approaches to gauge the attitude of students to online learning [34].

In determining teaching methods used in the process of studies, the following types are going to be discussed further down below: lecture, seminar, conference, cooperative learning, webinar, quiz, discussion, brainstorming, group work, case study, project and research study.

Traditional teaching methods distinguish between lectures and seminars. While lectures are based on hierarchical transfer of information from the lecturer to 
the students, the seminars are interactive because they are structured group discussions led by the teacher and differ from discussions in the use of specialized questions and a more formal process in which they take place $[35,36]$. A seminar can involve group work focusing on problem solving or presenting a question to students to learn. Due to their interactivity and focus on specific issues and problems, as well as the practical application of knowledge gained from other sources, seminars or horizontal knowledge transfer can be a good way to work with Generation Z students [7].

Seminars as a method of online study is increasingly present in the form of webinars, with students being able to plan their time more efficiently which also leads to improved results [37]. In online webinars, socialization between students and the teacher is essential. In online format, students are able to see the presentation before the webinar, so that if something is unclear, they can prepare questions in advance $[33,38]$. Solutions for providing seminars with holographic video transmission are considered, which can be used in future for employing seminars and conferences online; this would in turn give the students and teachers a feeling of being in one room, making distance study process similar to an in-person one [39].

Apart from seminars, other interactive teaching methods include brainstorming, group work, case studies and discussions, which can all be integrated in seminar format. These methods facilitate interactivity and collaborative learning, involving learners in generating knowledge and communicating it to other learners.

Brainstorming is a useful method to facilitate the emergence of new ideas. The activity takes place in groups, and its goal is to actively generate new, free and creative ideas, which a single participant would be unlikely to do. Brainstorming has been found efficient in online settings and can be used in teaching Generation $\mathrm{Z}$ students $[40,41]$.
Group work enables the participants to work on a certain task, where participants decide to work on certain tasks either together or individually [42]. It is believed that students study better and are better at adopting to the labor market if their study programs include group work, involving students into the study process itself [43]. When offering group work to students, the teacher sets the themes and the result to be achieved. The number of participants per group is a subject of discussion, but it is considered that groups of four to five participants can execute the task efficiently without compromising the quality of work.

Case study is a teaching method that involves offering the students to express their opinion about a given situation either orally or in writing. The students solve the issue imagining themselves in various roles according to the situation and playing them out. There are no guidelines for performing the task, as they can be set according to each different situation, determining how the task is to be executed and whether the participants will have the knowledge, skills and abilities to perform the task. It is believed that case study facilitates a wider understanding of the material in students than using the classical approach in the form of lectures. When working on a case study, the students develop a multidimensional understanding of various complicated issues, including their ability to collaborate $[44,33]$. However, it is considered that case study has a number of drawbacks if students lack knowledge or if the task is not appropriate for their age group, which leads the task from deviating from the trajectory envisaged for it by the teacher [45].

Discussion as a way of online studies presents various challenges. As a way of study, discussion enables the teacher to check if the students have mastered the material, have understood it and can connect it with daily life, thus considering various issues and problems and seeking solutions to them, comparing opinions, experiences and facts. Generation $\mathrm{Z}$ 
students engage in discussion voluntarily and consider in depth the issues suggested by the teacher [46]. A number of discussion types are singled out, including debate, round table, pyramid discussion, plenary and punctuated discussion. Some types are particularly appropriate for distance study. A plenary discussion includes well-known themes, discussing prepared questions. A punctuated discussion focuses on performing a single task, dividing students into groups of two to four people. Asynchronous discussion is study using an online archive, where students can study the themes that were not studied online [47].

Project works and research studies are distinct from lectures in that, as in collaborative learning, learners are responsible for sourcing and interpreting information with guidance provided by the educator. Both of these study formats can be either individual (a learner doing a project him/herself) or interactive (a group of learners being given a project or a task to explore). A project work is defined as a unique event with a clearly defined aimed, which involves a process composed of coordinated and controlled activities with a set starting and concluding terms [48]. It is important to engage both experienced and new specialists in a project to obtain examples of good practice and exchange of experience, which is important in working on a real project [49]. Projects are associated with research studies, which can be described as experience gained through learning, enabling students to solve problems independently and creatively through observing, asking research questions, putting forth a hypothesis, suggesting solutions, planning work, collecting, analyzing and interpreting data, making conclusions and communicating the findings [50, 51, 52]. Project work and study through research are examples of practice-oriented learning, which has been cited as being particularly suitable for working with Generation Z students [15].

Interactive learning, in which learners are actively involved in generating and disseminating information, can be either individual or collaborative [53]. Collaborative learning is a technique that facilitates work in a group. Collaborative learning focuses on the learning aspect of working together, whereas group teaching focuses on what the lecturer does, rather than on students taking responsibility for their own learning in collaboration with others [31,54]. A sub-type of collaborative learning is the so-called cooperative learning: the difference between cooperative and collaborative learning is that the former tends to be teacher facilitated, whereas collaborative learning can be in informal spaces, often focusing on a group project without an instructor present [31]. These learning techniques are particularly suitable for a variety of educational contexts that arise with the development in technologies, the popularity of online education and restrictions imposed during Covid-19 pandemics.

Also sport teachers and coaches are looking for new methods to use with the learners. It is a challenge to provide education, including education in sport, online, using various activity applications available for phones, tablets, smart watches, etc. To engage and maintain the attention of Generation $\mathrm{Z}$ learners, teachers have to be creative, adapting teaching methods, particularly during the pandemic. Teachers have to record videos to explain the tasks, which can lead to stress situations for Generation $\mathrm{Z}$ learners, so that educators and coaches often have to work with leaners individually, communicating with them over online platforms or by mobile phone $[32,55]$. Studies show that $53 \%$ of people in the world use the Internet, of them $42 \%$ use various social media, the most popular being Facebook and Instagram, which during the pandemic are among the most efficient means of communication, thus offering new and adapted teaching methods [55]. 


\subsection{Selecting and adapting sport activities teaching methods for Generation $\mathbf{Z}$}

Research into physical activities, sport and sport education is a growing field, as Goodyear and Bundon underline [56] The findings of the present study of sport activities in Generation $\mathrm{Z}$ students in Latvia correlate with studies conducted elsewhere in the world, highlighting the challenges of distance learning in physical education during Covid-19 [57, 58]. Thus, studies conducted by researchers elsewhere in Europe highlight the need for teachers to adjust the existing teaching methods to the new setting in order to engage Generation $\mathrm{Z}$ students, which is considered to be a challenge. Filiz and Konukman affirm that physical activities teachers online classes should follow a value-oriented approach that includes socialization, interaction/communication, teaming, problem solving and cooperation [59]. Other researchers likewise highlight the inefficiency of the current teaching framework and the need to adapt it to engage young students over distance [60, 61]. Thus, Adedoyin and Soykan believe that online education is deeply rooted in adequate instructional design and development with a number of available theories and models, but that the online education process is becoming questionable due to the pandemic [62]. Moreover, Beard and Konukman stress the need to pay particular attention when teaching physical education in digital environment to such constituents as "cooperation between students", "active learning scenarios", timely and prompt feedback, etc. [63]. These considerations are particularly important in selecting appropriate teaching methods for the delivery of instruction in physical activities to Generation Z.

In difference from the older generations, Generation Z grew up with the use of gadgets and digital technologies, which makes them especially responsive to virtual learning opportunities, the use of technologies as part of the learning process, as well as the use of visual materials. This is the first generation that reads printed text less and which has a strongly pronounced tendency towards visual perception of the world, and which, from an earlier age, possesses own objects for which they hold a copyright [7]. Generation $\mathrm{Z}$ recognizes the extent to which technologies and robotization have entered the working environment and the need for lifelong learning and changing their profession, not just their workplace in labor market, from time to time.

At the same time, certain characteristics of this generation have to be observed when selecting the most appropriate learning methods and environments. Thus, the preference for instant gratification means that Generation $\mathrm{Z}$ responds better to learning methods and tools that involve quick access to information and the provision of instant feedback, such as online quizzes. Shorter attention span means Generation Z students are less likely to concentrate on studying big chunks of text in depth or to engage in detailed analysis of a problem. Meanwhile, it has been noted that educators need to provide Generation $\mathrm{Z}$ students with strict guidelines and criteria for selecting information and discriminating between the worthier and the less deserving sources of information. Accordingly, Seemiller and Grace state that, for Generation Z, education is less about the transfer of knowledge from teacher to student and more about helping students make sense of the overabundance of information available [18]. Generation $\mathrm{Z}$ are described as visual learners, as different from the previous generation. While the previous generations learn from written sources, Generation $\mathrm{Z}$ learn better from visual materials $[2,3,6]$. The use of education videos, from YouTube, Vimeo, and other platforms is advisable.

Another characteristic of Generation $\mathrm{Z}$ that must be taken into account when selecting or adopting teaching methods for Generation $\mathrm{Z}$ is their 
preference for interactive learning and for deciding themselves about the content they want to learn and the way they want to do it. According to Seemiller and Grace, Generation $\mathrm{Z}$ students prefer a facilitative approach to learning rather than an authoritative approach, where students can become connected with the course material, their peers, and their professors [18]. Thus, Cilliers stresses that Generation $Z$ learners are characterized by demand for instant information, visual forms of learning, and replacing "communication" with "interaction" [6].

It has been emphasized that representatives of this generation are also particularly interested in "applied learning," because they always want to see how applicable the information they acquire is in their daily life [8]. Similarly, Iftode postulates that Generation Z students are focused on practical study methods with direct implications or connection to real life [15]. They are likewise interested in problem solving, which provides a clue about the kind of teaching methods appropriate for this group of learners. Thus, such methods as case studies and problemfocused discussions would be particularly appropriate for teaching this group of young people.

While socialization is important for Generation $\mathrm{Z}$ representatives, and they are keen communicators in both virtual and real environments, in scholarly literature opinions about the importance of group works for this generation are controversial. On the one hand, Generation $Z$ representatives prefer interactive learning methods, which allow them to communicate and participate in producing learning content rather than being passive receivers of information in the form of traditional lectures. On the other hand, Generation $\mathrm{Z}$ has been characterized in literature as "disengaged from society" and "individualistic" [8, 56, 57]. Hence, they may feel that, in group work, their contribution is not sufficiently appreciated in the course of such group work as working on a project. Also, because of their busy lifestyle, they may lack the time and motivation necessary to engage in group work.

Because of the shorter attention span associated with Generation Z students and their preference for instant gratification, the pedagogic approach of edutainment is particularly suitable when working with this group of learners. "Edutainment" is an English term coined by combining the words "education" and entertainment". Edutainment is "entertaining education or educational entertainment" and implies socializing the audience by embedding lessons in any known way of entertainment: films, TV shows, computer games, music, multimedia software, websites, etc. [2, 58]. Interactivity is a key feature of edutainment, so that this approach targets both the demand for "being entertained" and the desire to interact and use modern gadgets and technologies. In particular, the use of education games and quizzes, such as Kahoot!, Quizlet and others, is likely to minimize distractions, thereby improving the quality of teaching and learning beyond what is provided in conventional classrooms [59]. For teaching sport activities specifically, various platforms and websites can be used, for instance, My Fitness Pal, Strava: Run \& Ride, My Fitness Pal, Runkeeper, etc. These quizzes are particularly well-adopted for use in the virtual or real classroom, because lecturers can freely create and integrate appropriate content, as well as engaging students in the creation of content, e.g., by designing a quiz. This possibility to create or adopt content caters for learners' predilection for flexibility $[15,60]$.

\section{Research methodology and results}

\subsection{Research methodology}

In the framework of the present study, a survey was conducted to find answers to the questions raised about the Generation's Z attitude towards sport activities, mental 
health, the spending of financial resources on health improvement and changes of the above during Covid-19 pandemic, as well as modern teaching methods and digital tools and websites for teaching sport activities. The survey named Fiziskās aktivitātes Covid-19 pandēmijas laikā [Physical activities during Covid-19 pandemic] was conducted during the spring of 2021. In total, answers were obtained and compiled from 697 respondents residing in Latvia, mostly students from social and exact field: the majority of the respondents were bachelor and master students from the University of Latvia, Riga Technical University and the Latvian Academy of Sport Education and pupils from secondary schools, especially Madona Gymnasium and Murjani Sport Gymnasium as well as others. The respondents were divided into the following age groups: from 16 to 19 (35\% of the participants), from 20 to 23 (46\% of the participants) and from 24 to $26(19 \%$ of the participants). The percentage of female participants amounted to $68.6 \%$, while male participants constituted $31.4 \%$ of the respondents.

The principle of sampling was based on the intention to include Generation Z's respondents who use modern teaching methods and tools. A Likert scale was employed, and the respondents were asked to evaluate the methods by giving them a quantitative value from 1 to 7 thus measuring the level of where " 1 " indicates "ineffective" and "7" indicates an effective teaching method or internet platform and website.

Hypothesis test for differences in respondents' answers about the attitude towards sport activity and changes during pandemic was carried out, with the following hypothesis having been formulated for the study:

H-1 Emergency situation during the pandemic causes depressive mood, thus influencing health and lifestyle.

H-2 The length and frequency of sport activities decreased during the pandemic.
H-3 During the pandemic-related emergency situation, increased attention is devoted to individual sport activities outdoors, where coaching services are not necessary, thus leading to a decrease of financial expenditure on sport activities.

Below are provided the formulas used for analyzing the results obtained I the questionnaire.

(1) The Chi Square statistic was used for testing relationships between categorical variables. The formula of Chi Square is as follows:

$\mathrm{X}^{2}$ - Chi Square obtained

$$
x_{c}^{2}=\sum \frac{\left(O_{i}-E_{i}\right)^{2}}{E_{i}}
$$

$c$ - degrees of freedom

$\Sigma$ - the sum of

$\mathrm{O}$ - observed frequency counts in each category

E - expected frequency counts in each category

(2) The Mann-Whitney U test was used to compare differences between two independent groups when the dependent variable is either ordinal or continuous, but not normally distributed.

$$
U_{\text {stat }}=\text { Rank Sum }-\frac{n(n-1)}{2}
$$

(3) ANOVA was used to assesses potential differences in a Scale-level dependent variable by a nominal-level variable having 2 or more categories [64].

$$
S^{2}=\frac{\sum(x-\bar{x})^{2}}{N-1}
$$

(4) Standard deviation was computed as a measure of dispersal in statistics.

$$
S D=\sqrt{\frac{\sum(x-\mu)^{2}}{N}}
$$

(5) The standard error of a statistic was computed as follows:

$$
S E_{\bar{x}}=\frac{S}{\sqrt{n}}
$$

(6) A confidence interval, in statistics, refers to the probability that a population parameter will fall between a set of values for a certain proportion of times (Fig.1. and Fig.2.) [65]. 


$$
\begin{aligned}
\text { SEM } & =\sqrt{x(n-1) / n^{3}} \\
\text { Lower } & =P-\left(Z_{\alpha} * S E M\right) \\
\text { Upper } & =P+\left(Z_{\alpha} * S E M\right)
\end{aligned}
$$

To test the hypothesis, a chi-squared test and Mann-Whitney U test were performed. All tests and subsequent computations were executed with JASP Team software (2021) Version 0.15 . and the $p$-value provided was verified:

If $\mathrm{p}$-value $>0.05$, $\mathrm{H}$-null is true,

If $p$-value $<0.05, \mathrm{H}$-alternative is true.

For investigating the differences within the group of respondents in the occurrence of depressive mood, the presence of sport activities and their preference for teaching methods, the results were analyzed by dividing the participants by age, gender and number of people per household. Age group $16-19$ years old accounted for $35.1 \%, 20-23$ years old for $45.9 \%$ and $24-26$ years old for $19 \%$ of respondents. By dividing the participants by gender, we see that $68.6 \%$ were female and $31.4 \%$, so that females constitute $2 / 3$ and males $1 / 3$ of the respondents. $62.2 \%$ of the respondents lived in households of 3-5 people, and the households of one person were rare $(6.2 \%)$, as well as those with over 6 people $(5.7 \%)$. A quarter of the respondents $(25.9 \%)$ lived in households with two people.

Table 1. Gender and Age Division of Respondents

\begin{tabular}{|c|c|c|}
\hline Variables & $\mathbf{n}$ & \% \\
\hline Gender & & \\
\hline Females & 466 & 68,6 \\
\hline Males & 213 & 31,4 \\
\hline Age group & & \\
\hline $16-19$ & 238 & 35,1 \\
\hline $20-23$ & 312 & 45,9 \\
\hline $24-26$ & 129 & 19 \\
\hline $\begin{array}{c}\text { Size of } \\
\text { household }\end{array}$ & & \\
\hline 1 & 42 & $6.2 \%$ \\
\hline 2 & 176 & $25.9 \%$ \\
\hline $3-5$ & 422 & $62.2 \%$ \\
\hline 6 and more & 39 & $5.7 \%$ \\
\hline
\end{tabular}

\subsection{Research results and discussion}

The results of the survey among Generation $\mathrm{Z}$ Latvians have led to a number of important findings. In the first stage, Generation $\mathrm{Z}$ assessed their sport activity, smoking and drinking habits, and the presence of depressed moods. The respondents were asked to assess their habits on a Likert scale of 1-7, and standard deviation was calculated for this variables (see Table 2).

Table 2. Characteristics of respondents' smoking habits and presence of depressive mood during the pandemic

\begin{tabular}{|l|c|c|c|c|}
\hline \multicolumn{1}{|c|}{ Variables } & n & Mean & SD & p \\
\hline Smoking & 679 & 1.804 & 1.449 & 0.247 \\
\hline $\begin{array}{l}\text { 6 people in } \\
\text { a } \\
\text { household }\end{array}$ & 39 & 2.205 & 1.38 & $\mathbf{0 . 0 0 1}$ \\
\hline Female & 466 & 2.822 & 1.379 & $\mathbf{0 . 0 0 8}$ \\
\hline $\begin{array}{l}\text { Depressive } \\
\text { mood in } \\
\text { females }\end{array}$ & 466 & 4.854 & 1.651 & $\mathbf{0 . 0 0 1}$ \\
\hline $\begin{array}{l}\text { Females } \\
\text { aged 20 - } \\
23\end{array}$ & 312 & 4.747 & 1.641 & $\mathbf{0 . 0 2 7}$ \\
\hline
\end{tabular}

Source: computed using JASP Team (2021). JASP (Version 0.15) [Computer software].

As can be seen from Table 2, Generation $\mathrm{Z}$ smoking habits have not undergone any substantial change, as shown by Mann-Whitney U test ( $\mathrm{p}=0.247)$. The use of alcohol is less pronounced in families with 6 or more people, as confirmed by ANOVA test $(\mathrm{p}=0.001)$, also confirming hypothesis $\mathrm{H}-1$. The questionnaire results showed that alcohol is used by women more often than by men during the pandemic (Mann-Whitney $U$ test: $\mathrm{p}=0.008)$. Depressive mood is more present in women, too, as confirmed by Mann-Whitney U test $(p=0.001)$, especially in age group $20-23$ years old, as shown by ANOVA test $(\mathrm{p}=0.027)$ : this may testify to an increase in the use of alcohol among female youths during the pandemic; alcohol is used more often by respondents from 
households with one or two people, with females using alcohol more often possibly due to the presence of depressive mood.

The pandemic has also left considerable impact on the daily performance of sport activities, which can be performed consciously to strengthen and improve general physical condition and facilitate health improvement.

Table 3 Comparison of sport activities of Generation $\mathrm{Z}$ and the expenditure of financial resources before and during COVID-19 pandemic

\begin{tabular}{|c|c|c|c|c|}
\hline Variables & $\mathbf{n}$ & Mean & SD & p \\
\hline Sport activities before the pandemic & 679 & 4.947 & 1.713 & \multirow{2}{*}{0.001} \\
\hline Sport activities during the pandemic & 679 & 4.158 & 1.77 & \\
\hline $\begin{array}{l}\text { Comparison of activities by males and females before the } \\
\text { pandemic - males }\end{array}$ & 213 & 5.315 & 1.685 & \multirow[t]{2}{*}{0.01} \\
\hline females & 466 & 4.779 & 1.702 & \\
\hline $\begin{array}{l}\text { Comparison of activities by males and females during the } \\
\text { pandemic - males }\end{array}$ & 213 & 4.427 & 1.817 & \multirow[t]{2}{*}{0.001} \\
\hline females & 466 & 4.034 & 1.736 & \\
\hline Financial spending before and during the $\mathrm{p}$ & 679 & 3.287 & 1.496 & 0.015 \\
\hline Health before the pandemic & 679 & 5.49 & 1.218 & \multirow{2}{*}{0.001} \\
\hline Health during the pandemic & 679 & 4.61 & 1.545 & \\
\hline Health before the pandemic - males & 213 & 5.61 & 1.329 & \multirow{2}{*}{0.017} \\
\hline Health before the pandemic - females & 466 & 5.436 & 1.161 & \\
\hline Health during the pandemic - males & 213 & 4.901 & 1.54 & \multirow{2}{*}{0.001} \\
\hline Health during the pandemic - females & 466 & 4.476 & 1.53 & \\
\hline
\end{tabular}

Source: computed using JASP Team (2021). JASP (Version 0.15) [Computer software].

As shown by the results of the questionnaire summarized in Table 3, during the pandemic the young people's sport activities underwent a substantial reduction (Mann-Whitney $\mathrm{U} ; \mathrm{p}=0.001$ ): albeit among the respondents Generation $\mathrm{Z}$ males of all age groups engaged in sport activities slightly less than before the pandemic $(\mathrm{p}=0.01)$, females experienced a substantial drop in sport activities $(p=0.001)$. Thus hypothesis $\mathrm{H}-2$ was confirmed, in that the frequency of sport activity decreased during the pandemic. Female respondents stated that they usually devote 91 - 150 minutes a week to sport activities (Chi-Squared Test, $\mathrm{p}>0.001$ ), whereas male respondents mostly spend $151-300$ minutes a week engaging in sport activities, with the exception of males aged $24-26$, who mostly spend 91-150 minutes a week on sport activities. It should be noted that under the influence of the pandemic not only the frequency of sport activities decreased, but so did financial expenditure on sport activities. The case in point are female respondents, who spent less on sport activities (Mann-Whitney U test, $p=0.015$ ), whereas age group $20-23$ years old experienced the most dramatic drop in financial expenditure (ANOVA test, $\mathrm{p}=0.031)$. The data collected in the study show that most respondents $(84 \%)$ spend under 20 EUR a month on sport activities. It was found that the most substantial financial resources are spent on the sport activities that amount to at least 301 minute a week or more. This shows that those youth who engage in sport activities more often also spend more money on them, as confirmed by Chi-Squared Test $(p=0.001)$. Coaching or instructor services are most often used by female respondents, as shown by Mann-Whitney $U$ test 
$(p=0.011)$, who would also like to use these even more often $(p=0.001)$. Hereby, H-3 hypothesis about the reduction of financial resources spent on sport activities during the pandemic was confirmed. In selfevaluation of health, a substantial difference was found in Mann-Whitney $U$ test, where $p=0.001$. In the study, male youths assess their health better than female respondents, as also shown by MannWhitney U test, where $\mathrm{p}=0.001$ before the beginning of the pandemic and $p=0.017$ during the pandemic. Thus, during the pandemic, the frequency of sport activities and the time spent on them is substantially reduced as compared to the time before the pandemic, and self-assessment of one's health is also lower during the pandemic.

The second half of the questionnaire is devoted to teaching

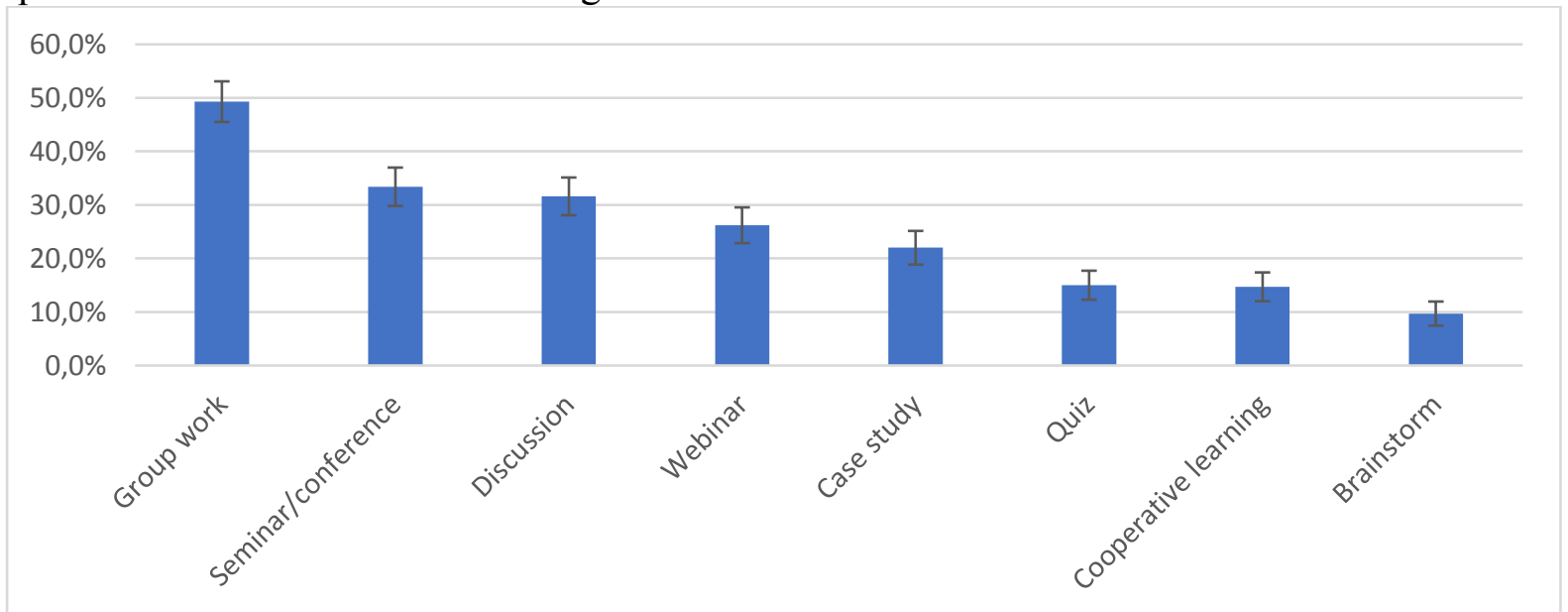

Fig.1 Ranking of sport activities teaching methods for Generation Z

Still, considering the choice of teaching methods by age groups, it was found that respondents aged 16-19 do not favor group work $(\mathrm{p}=0.05)$, seminars and conferences $(p=0.002)$ and webinars $(p=0.001)$ (Table 4$)$, albeit other age groups do not mind these teaching methods, as shown by Chi-Squared Test ( $\mathrm{p}>0.05)$. methods for sport activities and the modern gadgets and technologies, as well as websites, used by the respondents.

Analyzing the questionnaire answers on the choice of teaching methods, the following were found to be most popular: group work, seminars, conferences, discussions, webinars and case studies (as Fig. 1 indicates). It was determined that webinars are most popular among females, as confirmed by Chi-Squared Test $(\mathrm{p}=0.001)$.
Table 4. Chi-Squared test for usage of teaching methods depending on Generation $\mathrm{Z}$ age group

\begin{tabular}{|l|c|c|}
\hline \multicolumn{1}{|c|}{ Variables } & $\begin{array}{c}\text { Age } \\
\text { group }\end{array}$ & p \\
\hline Group work & $24-26$ & 0.05 \\
\hline $\begin{array}{l}\text { Seminars \& } \\
\text { conferences }\end{array}$ & $16-19$ & 0.002 \\
\hline Webinars & $16-19$ & 0.001 \\
\hline
\end{tabular}

In answering about websites and platforms used for facilitating sport activities, the respondents voted for YouTube and Instagram, with the younger respondents (aged 16-19) being more pronounced in preferring YouTube and Tiktok, whereas older respondents (aged 
20-23) preferring Instagram, and the oldest respondents (aged 24-26) also choosing Facebook.

In analyzing websites that support sport activities, the following were mentioned: Nike Training Club, Facebook, Strava: Run \& Ride Training, My Fitness Pal and Runkeeper (Fig. 2).

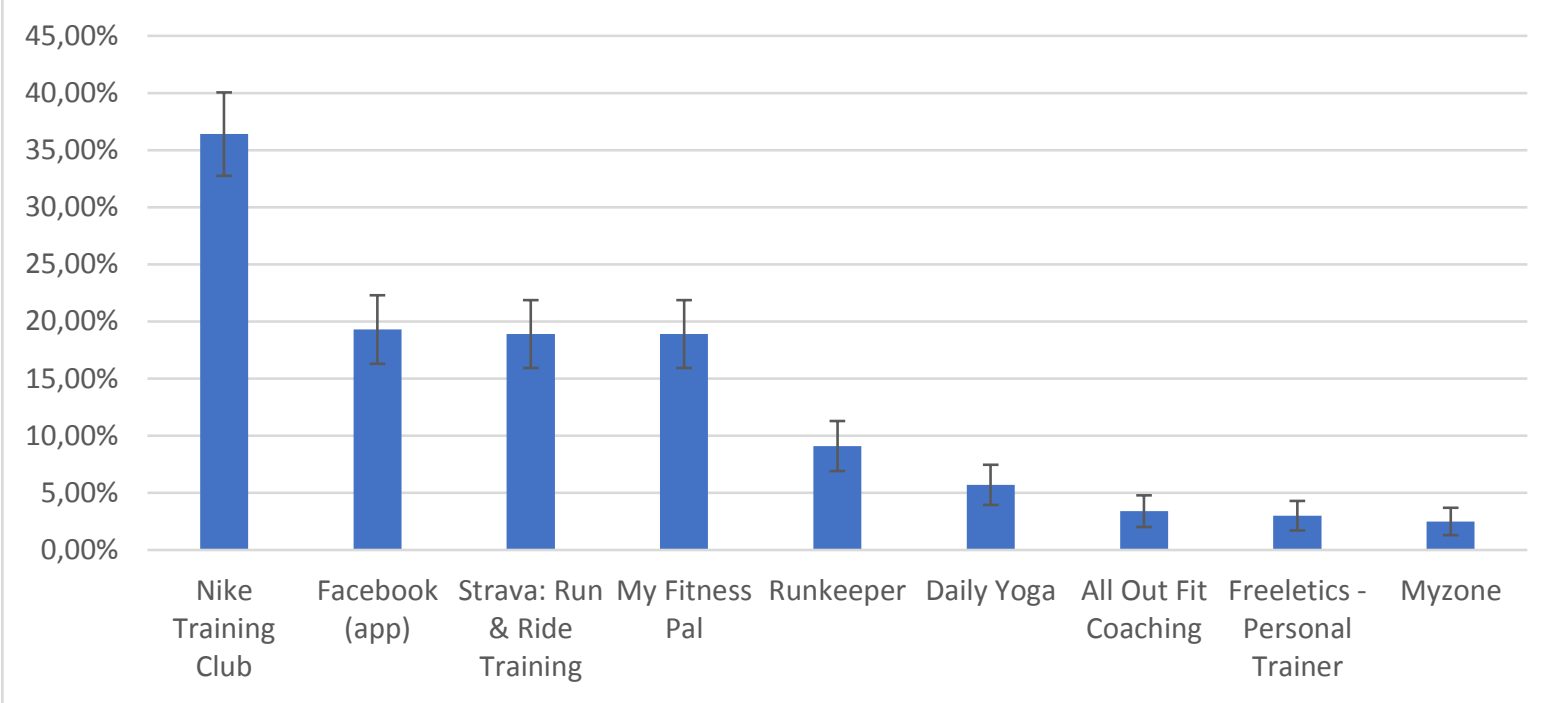

Fig.2 Ranking of sport activities promoting websites for Generation Z

As Figure 2 shows, the most popular website for Generation Z sport activities is Nike Training Club which is used by more than $35 \%$ of respondents. Next, the Facebook application is mentioned by almost $20 \%$ respondents, with Strava: Run \& Ride Training and My Fitness Pal enjoying a comparable level of popularity. Other websites, such as Runkeeper, and, next to it, Daily Yoga, are less popular. The three least popular website All Out Fit Coaching, Freelitics Personal Trainer and Myzone.

Further, the authors studied the peculiarities of age and gender in their use of websites, with Chi-Squared Test $(p=0.01)$ confirming that male respondents use Strava: Run \& Ride Training more often, whereas female participants prefer My Fitness Pal $(p=0.003)$. The study data confirm that respondents aged 16-19 prefer Runkeeper $(p=0.001)$, which is not a favorite among the older respondents.
Table 5. Chi-Squared Test for usage of websites depending on Generation $\mathrm{Z}$ respondents' gender

\begin{tabular}{|l|c|c|}
\hline \multicolumn{1}{|c|}{ Variables } & Gender & p \\
\hline $\begin{array}{l}\text { Strava: Run \& Ride } \\
\text { Training }\end{array}$ & Male & 0.01 \\
\hline My Fitness Pal & Female & 0.003 \\
\hline $\begin{array}{l}\text { Runkeeper (age 16- } \\
\text { 19) }\end{array}$ & Male & 0.001 \\
\hline
\end{tabular}

Table 5 lays out the results of Chi-Squared Test for analyzing the usage of websites depending on Generation Z respondents' gender. It demonstrates that Strava: Run \& Ride Training and Runkeeper are more popular for males, but females prefer to exercise by doing fitness.

Overall, the results of the study show that Covid-19 pandemic left a substantial and negative impact on the health, active lifestyle and financial resources Generation $\mathrm{Z}$ spend on sport activities.

Studies conducted in various countries in the whole world in general and European countries in particular raise the question of internal unity among Generation $Z$ [3]. It has been found that there are significant differences in the 
profile of Generation $\mathrm{Z}$ in different parts of the world, in different European countries or even in one small country such as Latvia $[10,13]$.

Previous studies conducted in Latvia has found that Generation Z tertiary education students value opportunities provided by online learning settings [34]. Whereas the present study used quantitative methods, including a questionnaire, a study from Spain applied qualitative methods, conducting semistructured interviews with a group of 12 preservice physical education (PE) teachers during the pandemic [61]. For the most part during the Covid-19 pandemic, qualitative research has focused on the challenges of teaching Generation Z [27, 60]

Our survey results show there are significant differences between different age subgroups, genders and living conditions (number of people in household) in their sport activity, smoking and drinking habits, and the presence of depressive mood.

However, certain researchers, such as Benczik et al., mainly underline one essential feature of Generation $Z$ representatives, who spend so much time in virtual space: in times of crisis they tend to turn to virtual spaces, which negatively affects their sport and mental health [19]. Earlier studies revealed the fact that Generation Z prefers in-person feedback and communication in education [5, 24]. The survey results have shown that emergency situation during the pandemic causes depressive mood, thus impacting health and lifestyle.

In preference of teaching methods, the study's mainstream state representatives of this generation are focused on practical study methods with direct implications or connection to real life. Thus, such methods as case studies and problem-focused discussions would be particularly appropriate $[8,15]$. As our survey showed, the most popular methods among the respondents are group work, seminars, conferences, discussions, webinars and case studies.

On the one hand, other researchers claim that Generation $\mathrm{Z}$ has been characterized in literature as "disengaged from society" and "individualistic" [8, 56, 57]. Hence, they may feel that, in group work, their contribution is not sufficiently appreciated. Our study indicates that respondents of the youngest age group (1619) are less enthusiastic about group work, seminars and conferences.

The survey highlights the importance of developing sport activities teaching practices and tools following the opportunities created by digitalization and emergence of artificial intelligence. Mavlutova et al. emphasize that in order to stimulate students' motivation teachers should use developed practical tools like automatic interactive digital software [58].

In summary, a positive role-model that facilitates learning healthy life skills can be developed in a distance physical education setting. The link between the student and the teacher is important to ensure that learning takes place. The lack of direct interaction in the Covid-19 period has significantly highlighted how valuable this link is. This is a new challenge in teaching physical activities. Physical education teachers' motto should be "Guiding youngsters in the process of becoming physically active and healthy for a lifetime" [59]. The challenges of teaching sport activities and physical education during Covid-19 pandemic are shared by teachers from countries across the world [66]. This study shows the topicality of selecting and adapting teaching methods for sport in order to sustain the physical and mental health of young people.

\section{Conclusions}

Though Covid-19 has affected the physical activity as well as the physical, mental and social health of all age groups, Generation $\mathrm{Z}$, the representatives of the future labor market, are particularly vulnerable. With the reduction of opportunities for exercise 
and limited access to in-person coaching, the choice of teaching methods for Generation $\mathrm{Z}$ comes to the fore.

The current research highlights a change in Generation $\mathrm{Z}$ sporting practices under the influence of the pandemic, a raise in the use of alcohol by young females with the tendency being less pronounced in larger households. Also, the presence of depressive mood is more widespread among females than males, especially among females aged 20-23.

The period of the pandemic influenced the practices of Generation Z's performance of physical activities on a regular basis with the reduction of financial spending on sport, the use of coaching services, which had an impact on preferred teaching methods and the use of online platforms by the participants to gain information about sport.

Our survey of Generation $\mathrm{Z}$ in Latvia allows to conclude that the surveyed respondents highly value the application of interactive online teaching methods with the usage of modern gadgets and technologies; however, the evaluation of different methods differs significantly depending on the age and gender of the respondents.

We found positive correlation between age, gender, the occurrence of depressing mood or anxiety and engagement in physical activity and also identified that Generation Z spends less financial resources for their physical activities and well-being insurance (e.g., the empirical study shows that $84 \%$ of respondents spend under 20 hours per month on physical activity Chi-Square test $\mathrm{p}=0.001$ ); additionally, the study shows that the use of such teaching methods as and work in groups, seminars and webinars for promoting physical activities are efficient under the Covid-19 pandemic situation specially for responders 16 - 19 seminars and conferences $(p=0.002)$ and webinars $(p=0.001)$, albeit other age groups do not mind these teaching methods as well as group work, as shown, by Chi-Squared Test $(p>0.05)$. As various contemporary studies reveal, Generation $\mathrm{Z}$ require adaptation of physical activity to the changed circumstances.

During our research, no other indepth study of Generation Z sport activities in Latvia were conducted. Hence, certain limitations for generalizing the outcomes obtained from surveying Latvian Generation $\mathrm{Z}$ exist, as Latvian population income and attitude toward physical activities on a daily basis lag behind the Western European countries and is one of the lowest in the European Union.

During the study, we considered Generation Z's choice of teaching methods using digital tools and the facilities available to them for performing physical activities during the lockdown. The emphasis on online setting, which resulted from the restriction imposed during the outbreak of Covid-19, makes the present study particularly topical, as the findings show a decrease in Generation $\mathrm{Z}$ physical activity, accompanied by decrease in wellbeing and increase in the use of alcohol. Still, further research is needed to investigate and compare the attitudes in other geographical regions and countries.

Acknowledgments: The paper was founded within the framework of the LCS project "The Impact of COVID-19 on Sustainable Consumption Behaviors and Circular Economy (No. lzp-2020/2-0317)."

References:

[1] R. Regan, "Everything You Need To Know About Generation $\mathrm{Z}$ in The Workplace in 2021," [Online]. Available:

https://connecteam.com/generation-zin-the-workplace/. [Accessed 904 2021].

[2] N. A.Chumak and T. P. Andrienko, "Edutainment in teaching foreign 
language to generation $\mathrm{Z}$ students," in Наукові записки Національного університе ту «Острозька академія»: серія «Філологія», 2020, pp. 195-197.

[3] V. Sanalan and E. Taslibeyaz, "Discovering Generation Z," in Journal of Educational Issues Vol. 7, No. 2, 2020, pp. 249-268.

[4] M. Dimock, "Defining generations: Where Millenials end and Generation $Z$ begins," in Pew Research Center Factank. [Online]. Available: https://www.pewresearch.org/facttank/2019/01/17/where-millennialsend-and-generation-z-begins/. [Accessed 904 2021].

[5] A. Dolot and A. Grobelna, "The Role of Work Experience in Studying and Career Development in Tourism: A Case Study of Tourism and Hospitality Students from Northern Poland," in Entrepreneurial Business and Economics Review, Vol. 6, No. 4, 2018, pp. 217-229.

[6] E. J. Cilliers, "The Challenge of Teaching Generation Z," in PEOPLE: International Journal of Social Sciences, Vol. 3, No. 1, 2017, pp. 188198.

[7] Z. Rubene, "Jaunajai paaudzei ir vienaldzīga sociālā hierarhija," [Online]

Available: https://lvportals.lv/viedokli /299610-jaunajai-paaudzei-irvienaldziga-sociala-hierarhija-2018. [Accessed 904 2021].

[8] B. Demir and G. Sönmez, "Generation Z students' expectations from English language instruction," Journal of Language and Linguistic Studies, Vol. 17, No. 1, 2021, pp. 683-701.

[9] Z. Antosa and Y. Kiram, "Mapping the Learning Needs of Multicultural Generation Z Students," in Advances in Social Science, Education and Humanities Research, vol. 463. Proceedings of the Eighth International Conference on
Languages and Arts (ICLA-2019). Atlantis Press, 2020.

[10] C. Scholz and A. Rennig, Generations $Z$ in Europe: Inputs, Insights and Implications (Changing Context of Managing People), Emerald publishing, 2019.

[11] S. Weber and S. Dixon, Growing Up Online: Young People and Digital Technologies, Palgrave Macmillan US, 2007.

[12] A. Bencsik, G. Horvath-Csikos, T. Juhasz, and A. Csanadi, "Healthy lifestyle and behavior of $Z$ Generation," in Journal of Eastern European and Central Asian Research, Vol. 6, No. 2, 2019, pp. 297-308.

[13] K. Lesinskis, I. Mavlutova, L. Peiseniece, J. Hermanis, E. Peiseniece and O. Pokatayeva, "Modern Business Teaching: The Stable Market Provisions for Emerging Generations," in Journal Studies of Applied Economics (Estudios de Economía Aplicada) Exploring Sustainable Urban Transformation Concepts for Economic Development: Vol. 39, No. 5, 2021, pp. 1-7.

[14] S. Dixon, "Playspaces, Childhood, and Video games," in Growing Up Online: Young People and Digital Technologies, 17-36, Palgrave Macmillan US, 2007.

[15] D. Iftode, "Generation Z and Learning Styles," in SSRN Electronic Journal, Vol. 21 No. 3, 2019, pp. 255-262.

[16] B Demir and G. Sönmez, "Generation Z students' expectations from English language instruction," in Journal of Language and Linguistic Studies, Vol. 17, No. 1, 2021, pp. 683-701.

[17] S. Hilčenko, "How Generation " $Z$ " Learns Better?," in European Journal of Social Sciences, Vol. 11, No. 2, 2017, pp. 379-389.

[18] C. Seemiller and M. Grace, Generation $Z$ goes to college, Jossey-Bass, 2016.

[19] I. J. Benczik, "Edutainment in the Magic Tower: Environmental 
awareness as a lifelong learning process," Journal of Applied Technical and Educational Sciences, Vol. 9, No. 1, 2019, pp. 42-57.

[20] L. M. Helsingen et al., "The COVID19 pandemic in Norway and Sweden threats, trust, and impact on daily life: a comparative survey," in BMC Public Health, Vol. 20, 2020, p. 1597.

[21] De Matos et al., "The Impact of Methods Recommended by the Government to Limit the Spread of Coronavirus (COVID-19) on Physical Activity Levels, Quality of Life, and Mental Health of Brazilians," in Sustainability, Vol. 12, 2020, p. 9072.

[22] N. Imran, M., Zeshan and Z. Pervaiz, "Mental health considerations for children \& adolescents in COVID-19 Pandemic," in Pakistan Journal of Medical Science, Vol. 36, 2020.

[23] A.C.V. Bezerra, "Factors associated with population behavior during social isolation in the COVID-19 pandemic," in CiênciaSaúdeColetivo, Vol. 25, 2020, pp. 2411-2421.

[24] Z. E. Csobanka, "The Z Generation," Acta Technologica Dubnicae, Vol. 6, No. 2, 2016, pp. 63-76.

[25] A. Stahl, "How Generation-Z Will Revolutionize The Workplace," [Online]. Available: https://www.forbes.com/sites/ashleyst ahl/2019/09/10/how-generation-zwill-revolutionize-theworkplace/?sh=1aa501f $24 \mathrm{f} 53$ [Accessed 1104 2021].

[26] S. H. Mackenzie and J. Goodnow, "Adventure in the Age of COVID-19: Embracing Microadventures and Locavism in a Post-Pandemic World," in Leisure Sciences Vol. 40, 2020, pp. 1-8.

[27] R. Melo, D. van Rheenen and S. J. Gammon, "Nature sports: a unifying concept," in Annals of Leisure Research, Vol. 23, No. 1, 2020, pp. 118.

[28] E. O. Çobanoğlu, P. Tağrikulu, and A. C. Gül, "Games from Generation X to
Generation Z," in Universal Journal of Educational Research, Vol. 6, No. 11, 2018, pp. 2604-2623.

[29] M. Petersone, K. Ketners, D. Krievinš and I. Erins, "Strategic Purchasing and Health System Efficiency: Prospects for Health Sector Reform in Latvia," in WSEAS Transactions on Business and Economics, Vol. 17, 2020, pp. 41-50.

[30] B. J. Kooiman, et al., "Moving online physical education from oxymoron to efficacy," in Sport, Education and Society, Vol. 22, No. 2, 2015, pp. 230246.

[31] K. Fisher and C. Newton, "Transforming the twen ty-first-

century campus to enhance the netGeneration student learning experie nce: using evidencebased design to determine what wo rks and why in virtual/physical tea ching spaces," in Higher Education Research \& Dev elopment, Vol. 33, No. 5, 2014, pp. 903-920.

[32] H. Morgan, "Best practices for implementing remote learning during a pandemic," in The clearing house: a journal of educational strategies, issues and ideas, Vol. 93, No. 3, 2020, pp. $135-141$.

[33] S. Torrau, "Exploring teaching and learning about the Corona crisis in social studies webinars," Journal of social science education, Vol. 19, 2020, pp. $15-29$.

[34] M. Farneste, A. Apse, "Challenges and opportunities of English grammar acquisition by distance at the tertiary level," Baltic Journal of English Language, Literature and Culture, Vol. 11, 2021, pp. 4-20. Available: https://doi.org/10.22364/BJELLC.11. 2021.01. [Accessed 904 2021].

[35] R. Birziṇa, "Tradicionālās mācību metodes," [Online]. Available: http://skolai.daba.lv/proj_materiali/ma cibu_materiali/b/Tradic_macmetodes_ 
prezent_rb_b.pdf. [Accessed 904 2021].

[36] A. Kiscenko, O. Onzevs, J. Zommers, "Methodological Support for Economical Education by Using Information Technologies," in Procedures of Scientific Conference "Rural Areas Development in the North-western Macroregion of Poland under Conditions of State Reforms and European Integration", Szczecin, Poland, 21-24 June 1999, Vol. 2, 2000, pp. 219-223.

[37] C. Boukje, K. de Witte and W. Schelfhout, "The impact of teaching engagement in an interactive webinar series on the effectivness of financial literacy education," in British journal of education technology, Vol. 52, No. 1, 2021, pp. $411-425$.

[38] S. P. Gentry, J. M Chamberlain and C. E. Bronner, "Developing an online seminar to support students new to distance learning," in Advances in engineering education, Vol. 8, No. 4, 2020.

[39] N. Li and D. Lefevre, "Holographic teaching presence: participant experiences of interactive synchronous seminars delivered via holographic videoconferencing," in Research in learning technology, Vol. 28, 2020.

[40] M. K. Alshammari, "Effective Brainstorming in teaching social studies for elementary school," in American international journal of contemporary research. Vol. 5, No. 2, 2015, pp. $60-65$.

[41] C. E. Rizi, M. Najafipour, F. S. Dehghan, "The effect of the using the brainstorming method on the academic achievement of students in grade five in Tehran elementary schools," in Procedia - social and behavioral sciences, Vol. 83, 2013, p. 230 - 233.

[42] F. Misra and I. Mazelfi, "Longdistance online learning during pandemic: the role of communication, working in group, and self-direct learning in developing student's confidence," in Proceedings of the $3 r d$ international conference on Educational development and quality assurance (ICED-qa 2020). Atlantis Press, 2021.

[43] A. Burke, "Group work of effective teaching," in The journal of effective teaching. Vol. 11, No. 2, 2011, pp. 8795.

[44] Z. Çakmak and Ì.H. Akgün, "A theoretical perspective on the case study method," in Journal of education and learning. Vol. 7, No. 1, 2018, pp. $96-102$.

[45] H. M. Niemi and P. Kousa, "A case study of students' and teachers' perceptions in a Finnish high school during the COVID pandemic," in International Journal of Technology in Education and Science (IJTES). Vol. 4, No. 4, 2020, pp. 352 - 369.

[46] K. J. Wilson, "Online discussions in biochemestry to increase peer interactions and student interest," in Biochemistry and molecular biology education, Vol. 49, No. 2, 2021, pp. 298-300.

[47] J. L. Bailie, "Online learner analytics of asynchronous discussions as a predictor of final grades," Journal of instructional pedagogies, Vol. 24, 2020.

[48] J. Uzulāns, "E-studiju metodika un didaktika," [Online].

[49] M. Salminen-Tuomaala and T. Koskela, "How can simulation help with learning project work skills? Experiences from higher education in Finland," in Educational Research, Vol. 62, No. 2, 2020, pp. 77 - 94.

[50] W. Rattanaprom, "Failure of researchbased learning implementation in basic education," in International Education Studies, Vol. 12, No. 4, 2019, pp. 19 23.

[51] P. DeWitt, "Using the visible learning research to influence collaborative leadership," in Educational sciences, Vol. 8, 2018. 
[52] D. Kalniņa, L. Mackēviča, "Mācību metožu vārdnīca," [Online]. Available: http://profizgl.lu.lv/mod/glossary/vie w.php?id=12204\&mode\&hook=ALL \&sortkey\&sortorder\&fullsearch $=0 \& p$ age $=-1$. [Accessed 904 2021].

[53] I. Mavlutova, K. Lesinskis, M. Liogys, and J. Hermanis, "The Role of Innovative Methods in Teaching Entrepreneurship in Higher Education: Multidisciplinary Approach," in Reliability and Statistics in Transportation and Communication, pp. 684-693, Springer, 2020.

[54] P. Sudarmika et al., "Comparison between Group Discussion Flipped Classroom and Lecture on Student Achievement and Student Characters," in International Journal of Instruction, 2020.

[55] N. Ozturk, E. B. Altan, A. Y. Turkoglu, "Discussing SocioScientific Issues on Twitter: The Quality of Pre-Service Science Teachers' Arguments," in Journal of education in science, Environment and health, Vol. 7, No. 1, 2021, pp. $72-85$.

[56] V. Igel and I. Urquart, "Generation Z, Meet Cooperative Learning," in Middle School Journal (J3), Vol. 43, No. 4, 2012, pp. 16-21.

[57] M. Töröcsik, K. Szücs and D. Kehl, "How Generations Think: Research on Generation Z communication," in Actauniversitatis Sapientiae, Vol. 1, 2014, pp. 23-45.

[58] I. Mavlutova, K. Lesinskis, M. Liogys and J. Hermanis, "Innovative teaching techniques for entrepreneurship education in the era of digitalization," in WSEAS Transactions on Environment and Development, Vol. 16, 2020, pp. 725-733.

[59] B. Filiz, F. Konukman, "Teaching Strategies for Physical Education during the COVID-19 Pandemic," Journal of Physical Education, Recreation \& Dance, Vol. 91:9, 2020, pp. 48-50.
[60] V. Goodyear, A. Bundon, (2021) "Contemporary digital qualitative research in sport, exercise and health: introduction," in Qualitative Research in Sport, Exercise and Health, Vol. 13, No. 1, 2021, pp. 1-10.

[61] V. Varea, G. González-Calvo, A. García-Monge, "Exploring the changes of physical education in the age of Covid-19," in Physical Education and Sport Pedagogy, 2020.

[62] O. B. Adedoyin, E. Soykan, "Covid-19 pandemic and online learning: the challenges and opportunities, Interactive Learning Environments," in Interactive Learning Environments, Vol. 1, 2020, pp. 1-13.

[63] J. Beard and F. Konukman, "Teaching Online Physical Education: The Art of Connection in the Digital Classroom," in Journal of Physical Education, Recreation \& Dance, Vol. 91, No. 7, 2020, pp. 49-51.

[64] Statistics Solutions. [Online]. Available:

https://www.statisticssolutions.com [Accessed 904 2021].

[65] Sample Size Calculators. [Online]. Available: https://sample-size.net. [Accessed 904 2021].

[66] S. McNamara, B. Weiner, D. Martinez, H. Ambrosius, A. Griffin, A. Beavers, J. Heebink, "The Impact of COVID-19 on Teachers' Ability to Navigate the Delivery of APE Services," Journal of Physical Education, Recreation \& Dance, Vol. 92, No. 7, 2021, 10-15.

\section{Creative Commons Attribution License 4.0 (Attribution 4.0 International, CC BY 4.0)}

This article is published under the terms of the Creative Commons Attribution License 4.0

https://creativecommons.org/licenses/by/4. 0/deed.en U 